\title{
Interactions of whey proteins with milk fat globule membrane proteins during heat treatment of whole milk
}

\author{
Aiqian YE ${ }^{\mathrm{a}}$, Harjinder SINGH ${ }^{\mathrm{a} *}$, Michael W. TAYLOR ${ }^{\mathrm{b}}$, Skelte ANEMA ${ }^{\mathrm{c}}$ \\ ${ }^{a}$ Riddet Centre, Massey University, Private Bag 11 222, Palmerston North, New Zealand \\ b Institute of Food, Nutrition and Human Health, Massey University, Private Bag 11 222, \\ Palmerston North, New Zealand \\ ${ }^{\mathrm{c}}$ Fonterra Research Centre, Private Bag 11 029, Palmerston North, New Zealand
}

Received 4 June 2003 - Accepted 4 September 2003

Published online 26 March 2004

\begin{abstract}
The association of $\beta$-lactoglobulin $(\beta-\mathrm{Lg})$ and $\alpha$-lactalbumin $(\alpha-\mathrm{La})$ with milk fat globule membrane (MFGM), when whole milk was heated in the temperature range $60-95^{\circ} \mathrm{C}$, was investigated using one- and two-dimensional sodium dodecyl sulfate polyacrylamide gel electrophoresis (SDS-PAGE) under reducing and non-reducing conditions. In SDS-PAGE under reducing conditions, $\beta$ - $\mathrm{Lg}$ was observed in MFGM material isolated from milk heated at $\geq 60{ }^{\circ} \mathrm{C}$ for $10 \mathrm{~min}$; small amounts of $\alpha$-La and $\kappa$-casein were also observed in the MFGM material of milk heated at $\geq 65^{\circ} \mathrm{C}$ for $10 \mathrm{~min}$ and $\geq 75^{\circ} \mathrm{C}$ for $10 \mathrm{~min}$, respectively. However, these proteins were not observed in SDS-PAGE under non-reducing conditions. Two-dimensional SDS-PAGE of MFGM material isolated from heated milk showed that the protein complexes that remained at the top of the nonreducing gel (first dimension) were resolved into $\beta-\mathrm{Lg}, \alpha$-La and the major original MFGM proteins in the reducing gel (second dimension). These results indicate that $\beta$-Lg and $\alpha$-La associated with MFGM proteins via disulfide bonds during the heat treatment of whole milk. The amounts of $\beta-\mathrm{Lg}$ and $\alpha$-La that associated increased with an increase in the temperature up to $80^{\circ} \mathrm{C}$, and then remained almost constant. These maximum values for $\beta$-Lg and $\alpha$-La were $\sim 1.0 \mathrm{mg} \cdot \mathrm{g}^{-1}$ fat and $\sim 0.2$ $\mathrm{mg} \cdot \mathrm{g}^{-1}$ fat, respectively. Of the major original MFGM proteins, xanthine oxidase and butyrophilin were not affected by the heat treatment of whole milk, whereas PAS 7 was heat labile and PAS 6 decreased to some extent during heating.
\end{abstract}

Milk fat globule membrane (MFGM) / $\beta$-lactoglobulin / $\alpha$-lactalbumin / SDS-PAGE / heat treatment

Résumé - Interactions des protéines sériques avec les protéines de la membrane des globules gras induites par le traitement thermique du lait entier. Les interactions de la $\beta$-lactoglobuline $(\beta-\mathrm{Lg})$ et de l' $\alpha$-lactalbumine $(\alpha-\mathrm{La})$ avec les composants de la membrane des globules gras (MFGM), contenues dans le lait entier, chauffé entre 60 et $95^{\circ} \mathrm{C}$, ont été étudiées par électrophorèse mono ou bi-dimensionnelle, en gel de polyacrylamide et dodécyl sulfate de sodium (SDS-PAGE) en conditions réductrices ou non. En conditions réductrices, les gels de SDS-PAGE indiquaient la présence de $\beta$ - $\mathrm{Lg}$ dans les MFGM isolés du lait chauffé dans des conditions $\geq$ à $60^{\circ} \mathrm{C}-10 \mathrm{~min} ;$ de faibles quantités d' $\alpha$-La étaient également détectées dans les MFGM pour ce même traitement thermique. Un traitement thermique plus intense $\left(\geq \mathrm{à} 75^{\circ} \mathrm{C}-10 \mathrm{~min}\right)$ montrait la fixation de caséine $\kappa$. Aucune de ces interactions n'était observée en conditions SDS-PAGE non réductrices. La caractérisation en SDS-PAGE bi-dimensionnelle des MFGM isolés du lait chauffé montrait que les complexes

\footnotetext{
* Corresponding author: H.Singh@massey.ac.nz
} 
protéiques qui restaient au sommet des gels non réducteurs ( $1^{\mathrm{e}}$ dimension) étaient résolus en $\beta$ - Lg, $\alpha$-La et composants protéiques majeurs des MFGM en conditions réductrices ( $2^{\mathrm{e}}$ dimension). Ces résultats confirment l'association de la $\beta$-Lg et de l' $\alpha$-La avec les protéines des MFGM par des liaisons $\mathrm{S}-\mathrm{S}$ lorsque le lait entier est soumis à un traitement thermique. Nos résultats montrent également que les quantités de $\beta$-Lg et d' $\alpha$-La ainsi fixées croissent avec l'intensité du traitement thermique jusqu'à $80^{\circ} \mathrm{C}-10$ min puis restent constantes. Les quantités maximales fixées étaient de l'ordre de $1,0 \mathrm{mg} \cdot \mathrm{g}^{-1}$ de matière grasse pour la $\beta$-Lg et de $0,2 \mathrm{mg}^{-1}$ de matière grasse pour l' $\alpha$-La. Enfin, parmi les composants protéiques des MFGM, la xanthine oxydase et la butyrophiline n'étaient pas affectées par le traitement thermique imposé au lait entier tandis qu'au contraire, les bandes correspondant aux glycoprotéines PAS 7 et 6 (periodic acid-Schiff reagent) thermolabiles décroissaient avec l'intensité du chauffage du lait.

Membrane du globule gras (MFGM) / $\beta$-lactoglobuline / $\alpha$-lactalbumine / SDS-PAGE bidimensionnelle / traitement thermique

\section{INTRODUCTION}

The fat globules in milk are surrounded and stabilized by the milk fat globule membrane (MFGM) which contains proteins, glycoproteins, enzymes, phospholipids, triacylglycerols, glycolipids and other minor compounds [15]. Over 40 bands of MFGM proteins can be resolved by sodium dodecyl sulfate polyacrylamide gel electrophoresis (SDS-PAGE) and several main individual proteins have been isolated and characterized [19]. Although the MFGM proteins account for only $0.03-0.04 \%$ of the total proteins in whole milk [20], many properties of dairy products are influenced by the responses of the MFGM components to various processes $[9,11,16,22]$. The MFGM is closely involved in natural processes in milk (e.g. creaming and agglutination) and is markedly affected by treatments such as cooling, heating and homogenization of dairy products [3].

Heat treatment causes a number of changes in MFGM proteins, which include some denaturation and interactions with serum proteins via sulfydryl-disulfide interchange reactions $[7,11,17,22]$. These studies showed that both $\beta$-lactoglobulin $(\beta-\mathrm{Lg})$ and $\alpha$-lactalbumin $(\alpha-\mathrm{La})$ bind to the fat globule when whole milk is heated. However, the mechanism by which these proteins interact with the fat globule is not clear. They may bind to the MFGM via sulfydryl-disulfide interactions [11]. Alternatively, the whey proteins may displace the original membrane material, either by directly competing or because MFGM may break down during heating, leaving gaps through which the whey proteins (which may or may not be denatured at that stage) may adsorb to the newly exposed fat surface [7]. Kim and Jimenez-Flores [17] also considered that the direct disulfide bonding between whey proteins and MFGM proteins could not completely explain their results and the precise nature of these interactions is not clear.

Houlihan et al. [11] reported that the quantities of $\beta-\mathrm{Lg}$ and $\alpha-\mathrm{La}$ on the MFGM increased, whereas the amounts of phospholipids and triacylglycerols decreased, with an increase in the heating time (from 2.5 to $20 \mathrm{~min}$ ) at $80^{\circ} \mathrm{C}$. $\alpha$-La was present at low levels in all heated samples. Low levels of $\kappa$-casein were also present and this component increased during heating. These results suggest that the MFGM is involved in heat-induced interactions with skim milk components, in particular $\beta-\mathrm{Lg}$ and $\kappa$-casein, and that the levels of incorporation of these components into the membrane are dependent on the extent of the heat treatments. $K$-casein may interact directly with MFGM components, and may interact with $\beta$-Lg through sulfydryldisulfide interchange during heating. 
Houlihan et al. [11] also found that xanthine oxidase, PAS 6 (Band 15) and PAS 7 (Band 16 or $49 \mathrm{~kg} \cdot \mathrm{mol}^{-1}$ ) decreased in intensity in the MFGM isolated from milk that was heated at $80^{\circ} \mathrm{C}$. The authors suggested that PAS 6 and PAS 7 might be displaced from the membrane by whey proteins during heating. In contrast, Kim and JimenezFlores [17] suggested that the $49 \mathrm{~kg} \cdot \mathrm{mol}^{-1}$ protein may have been cleaved into smaller molecular weight proteins after heat treatment.

In this present study, we attempted to characterize the interactions between milk serum proteins and MFGM proteins, during the heating of whole milk samples, obtained at different times during the New Zealand dairying season. SDS-PAGE, under non-reducing and reducing conditions, and two-dimensional SDS-PAGE were used, with a view to understanding the mechanism of binding of whey proteins to fat globules.

\section{MATERIALS AND METHODS}

\subsection{Materials}

Fresh whole milk was collected from the Massey University Dairy Farm, Palmerston North, New Zealand. Samples of early-, mid- and late-season milks were collected in August, January to March and May, respectively. In New Zealand, calving occurs in August and therefore these samples approximately correspond to early-, mid- and late-lactation milks.

All the chemicals used were of analytical grade obtained from either BDH Chemicals (BDH Ltd., Poole, England) or Sigma Chemical Co. (St. Louis, MO, USA) unless specified otherwise.

\subsection{Heat treatment of whole milk samples}

Fresh whole milk was heated in a pilotscale, indirect-heated, UHT plant (AlfaLaval, Lund, Sweden) to a desired temper- ature in the range $65-95^{\circ} \mathrm{C}$ and held for 0 $60 \mathrm{~min}$ in a temperature-controlled water bath. After holding the samples for set times, they were immediately cooled to about $20^{\circ} \mathrm{C}$ in an ice bath.

\subsection{Isolation of MFGM material}

MFGM material was isolated from whole milk, as described by Ye et al. [23]. A milk sample (unheated or heated) was centrifuged, and the top layer (cream) was removed and suspended in either 10 volumes of simulated milk ultrafiltrate (SMUF) [14] or SMUF containing $6 \mathrm{~mol} \cdot \mathrm{L}^{-1}$ urea and $50 \mathrm{mmol} \cdot \mathrm{L}^{-1}$ EDTA and left at room temperature for $1 \mathrm{~h}$. This mixture was recentrifuged and the top layer was collected. Washing in SMUF or SMUF containing urea and EDTA was repeated twice.

The total protein content and protein composition were analysed after each washing step. No significant changes in the natural MFGM proteins were found, but as expected the amounts of caseins (presumably trapped within the cream layer) decreased after the first and second washing. No caseins were observed at the MFGM of fresh raw milk after the third washing. Hence, the consistent washing times and steps during the experiments enabled the changes in the composition of the MFGM during processing to be accurately determined.

\subsection{Determination of protein and fat contents}

The total protein content of the top layer (cream) was determined using the Kjeldahl method [1]. The total fat contents of the whole milk and cream were determined using the Mojonnier method for milk [12] and cream [13], respectively.

\subsection{Analysis of MFGM protein components}

The individual proteins in the washed cream were determined by PAGE, as 
described by Ye et al. [23]. The gels were scanned using an Ultrascan XL laser densitometer and the results were analyzed using an LKB 2400 GelScanXL software program (LKB Produkter AB, Bromma, Sweden) to obtain quantitative results.

The quantitative analysis of the $\beta-\mathrm{Lg}$ and $\alpha$-La was carried out by using their respective standard curves. Standard samples of purified $\beta$-Lg and $\alpha$-La (Sigma Chemical Co.) were run on the electrophoresis gels in various amounts in the range $0.25-10 \mu \mathrm{g}$. A satisfactory linear plot $\left(\mathrm{R}^{2}=0.99\right)$ obtained between the integrated peak areas and the sample concentrations was then used to quantify the serum proteins in the samples derived from the MFGM.

Two-dimensional PAGE (first SDSPAGE non-reducing and then SDS-PAGE reducing) was used to identify the components in the protein complexes in MFGM material from heated milk samples. Twodimensional PAGE experiments were performed as described by Havea et al. [10].

Under non-reducing conditions, noncovalently-linked protein complexes were dispersed and migrated into the resolving gel, but disulfide-linked complexes remained at the top of the stacking and resolving gel. In contrast, under reducing conditions, both non-covalently-linked and disulfide-linked complexes were dispersed and migrated into the resolving gel. Thus, comparison of SDS-PAGE patterns under non-reducing and reducing conditions enabled disulfidelinkage complexes to be detected.

\subsection{Statistical analysis}

The results were analysed statistically using the Minitab 12 for Windows package. Differences were considered to be significant at $P \leq 0.05$.

\section{RESULTS}

An initial experiment showed that, when the milk was passed through the
UHT plant at room temperature, there was no effect on the MFGM protein composition and fat globule size (results not shown). This indicates that the flow conditions in the UHT plant did not damage the milk fat globules and that the MFGM remained intact. Consequently, any change in the composition of the MFGM was due to factors such as heating rather than experimental conditions in the UHT plant.

The proteins of the MFGM in washed cream, obtained from mid-season whole milk, that was heated at $60-95^{\circ} \mathrm{C}$ for $10 \mathrm{~min}$ were resolved by SDS-PAGE under both reducing and non-reducing conditions. The results are shown in Figures 1A and 1B, respectively. Similarly, the SDS-PAGE protein patterns of MFGM material isolated from milk heated at $70{ }^{\circ} \mathrm{C}$ for $2.5-$ $60 \mathrm{~min}$ are shown in Figure 2 and those of MFGM material isolated from milk heated at $65^{\circ} \mathrm{C}$ for $10-40 \mathrm{~min}$ are shown in Figure 3.

No bands corresponding to $\beta-\mathrm{Lg}, \alpha-\mathrm{La}$ or casein proteins were observed in unheated milk samples (Figs. 1, 2 and 3), indicating that serum proteins were not involved in the membrane. In SDS-PAGE under reducing conditions, the $\beta$ - $\mathrm{Lg}$ band was observed in MFGM material isolated from milk heated at $\geq 60{ }^{\circ} \mathrm{C}$ for $10 \mathrm{~min}$; the intensity of this band increased with an increase in heating temperature up to $75^{\circ} \mathrm{C}$ and then remained almost constant at higher temperatures (Fig. 1A). The $\beta-\mathrm{Lg}$ band was also found in milks heated at $70{ }^{\circ} \mathrm{C}$ for $\geq 2.5 \mathrm{~min}$ or $65^{\circ} \mathrm{C}$ for $\geq 10 \mathrm{~min}$; under these conditions, the intensity of the $\beta$ - $\mathrm{Lg}$ band increased with an increase in heating time (Fig. 2A and 3A).

The $\alpha$-La band was also observed in the MFGM material isolated from milk that was heated at $\geq 65{ }^{\circ} \mathrm{C}$ for $10 \mathrm{~min}$ (Fig. $1 \mathrm{~A}$ and $3 \mathrm{~A}$ ), whereas the $\mathrm{K}$-casein band was observed in milks heated at $\geq 75^{\circ} \mathrm{C}$ (Fig. 1A). In both cases, the bands were faint and fuzzy compared with the $\beta$ - $\mathrm{Lg}$ band.

Table I shows that the maximum amounts (obtained by quantitative PAGE) 
(A)

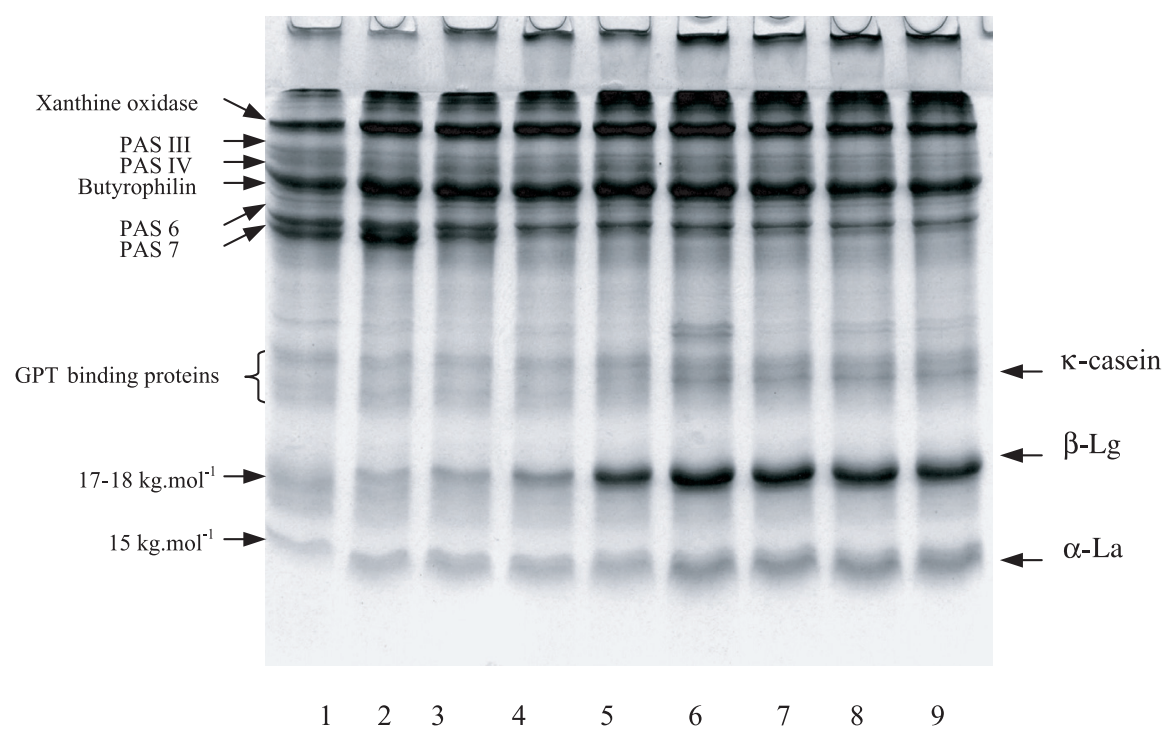

(B)

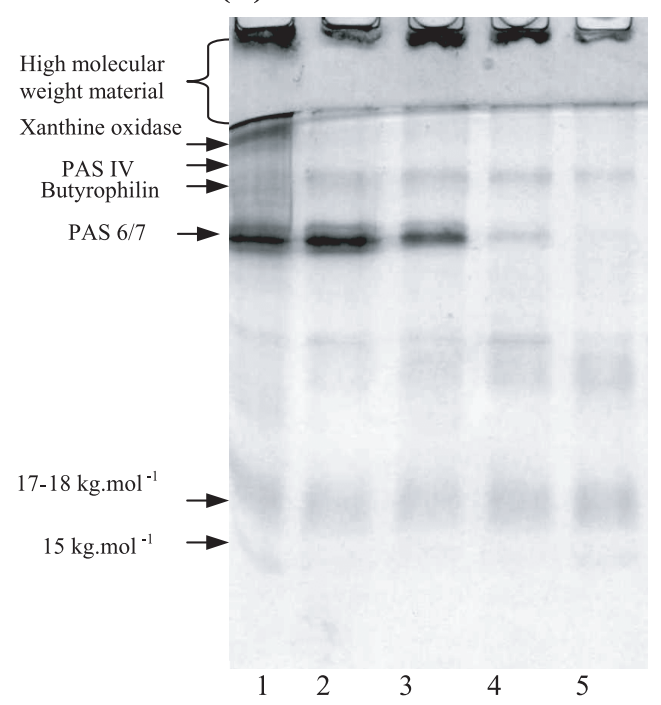

Figure 1. SDS-PAGE patterns (15\% acrylamide gel) of membrane material isolated from heated milk under reducing conditions (A) and non-reducing conditions (B). Cream obtained from the heated milks was washed in SMUF containing urea and EDTA. Lane 1: membrane material from unheated milk (control). Lanes 2-9: membrane material from milk heated at $60-95^{\circ} \mathrm{C}$, for $10 \mathrm{~min}$; (2) $60{ }^{\circ} \mathrm{C}$, (3) $65{ }^{\circ} \mathrm{C}$, (4) $70{ }^{\circ} \mathrm{C}$, (5) $75^{\circ} \mathrm{C}$, (6) $80^{\circ} \mathrm{C}$, (7) $85^{\circ} \mathrm{C}$, (8) $90{ }^{\circ} \mathrm{C}$ and (9) $95{ }^{\circ} \mathrm{C}$. Membrane polypeptides are named according to Mather [18]. 


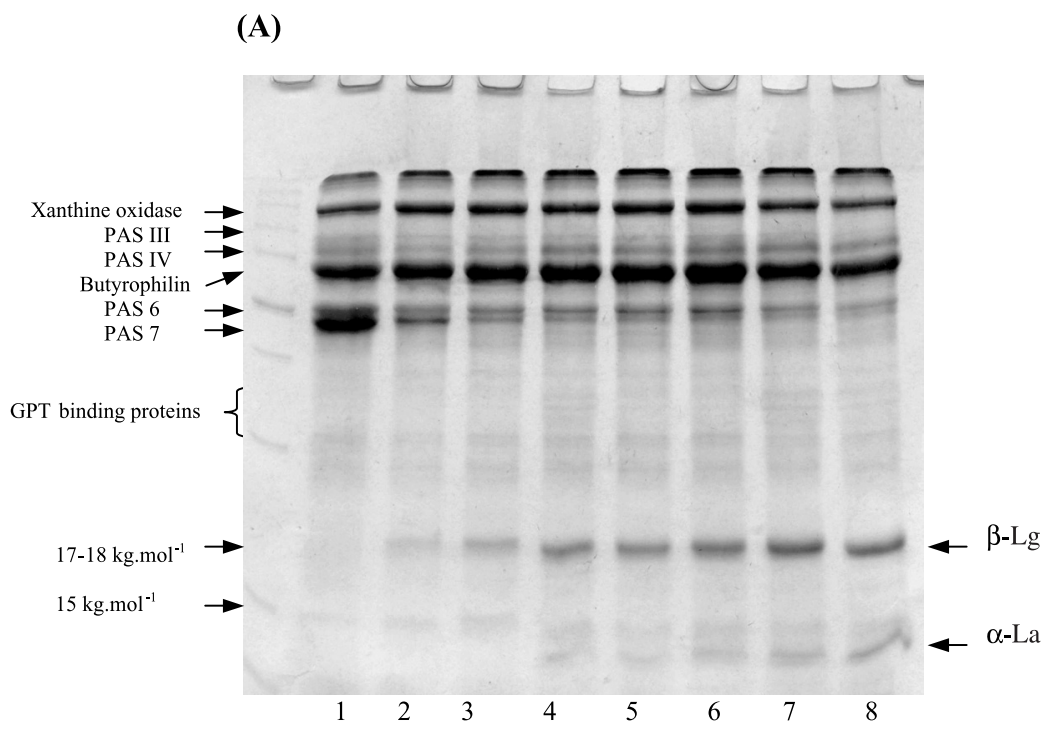

(B)

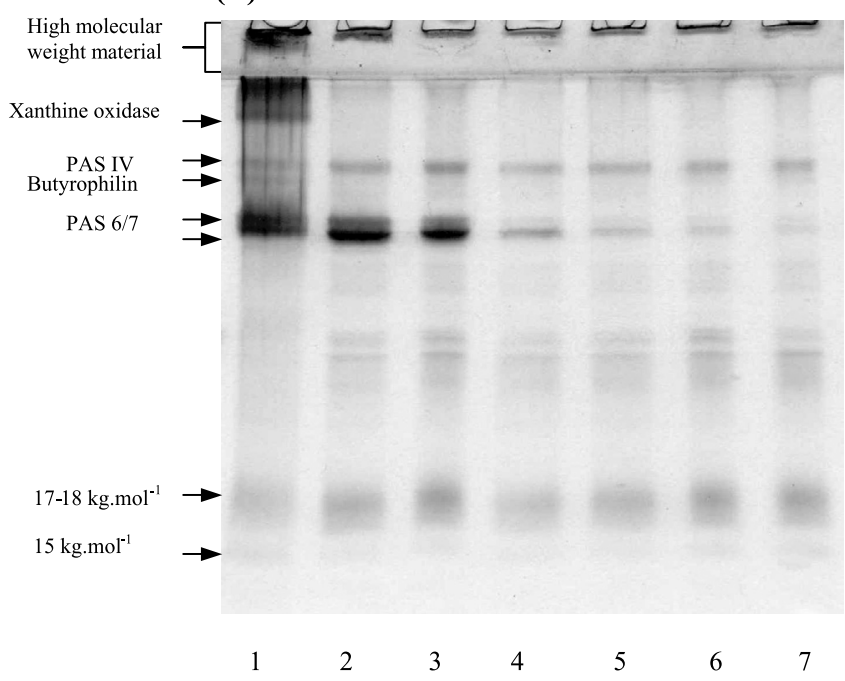

Figure 2. SDS-PAGE patterns (15\% acrylamide gel) of membrane material isolated from heated milk under reducing conditions (A) and non-reducing conditions (B). Cream obtained from the heated milks was washed in SMUF containing urea and EDTA. Lane 1: membrane material from unheated milk (control). Lanes 2-8: membrane material from milk heated at $70{ }^{\circ} \mathrm{C}$; for (2) $2.5 \mathrm{~min}$, (3) $5 \mathrm{~min}$, (4) $10 \mathrm{~min}$, (5) $20 \mathrm{~min}$, (6) $30 \mathrm{~min}$, (7) $40 \mathrm{~min}$ and (8) $60 \mathrm{~min}$. Membrane polypeptides are named according to Mather [18]. 


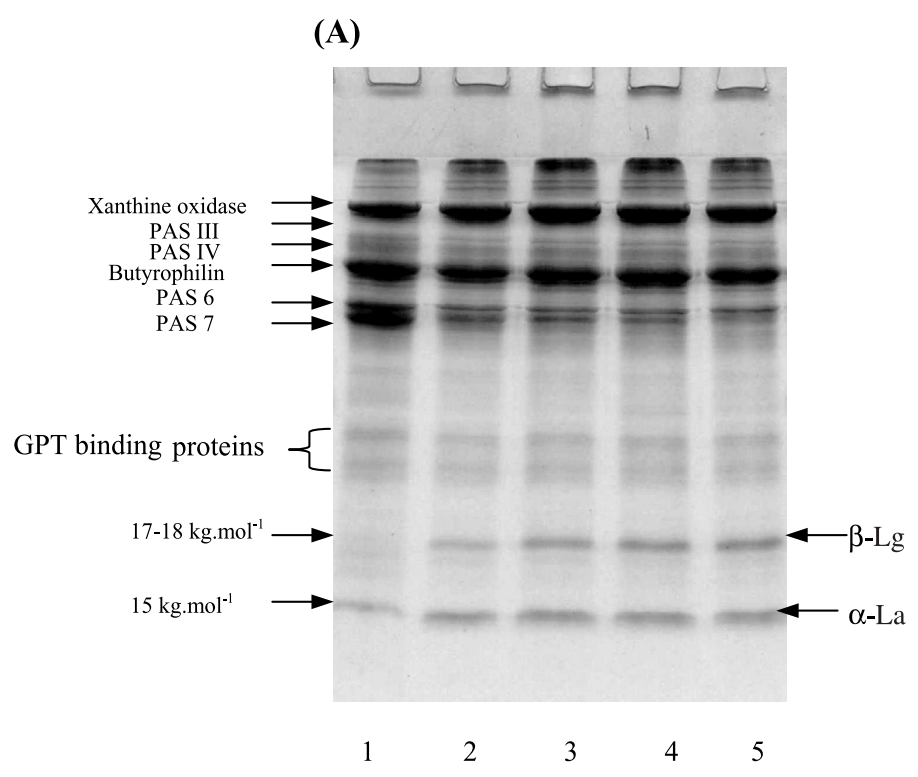

(B)

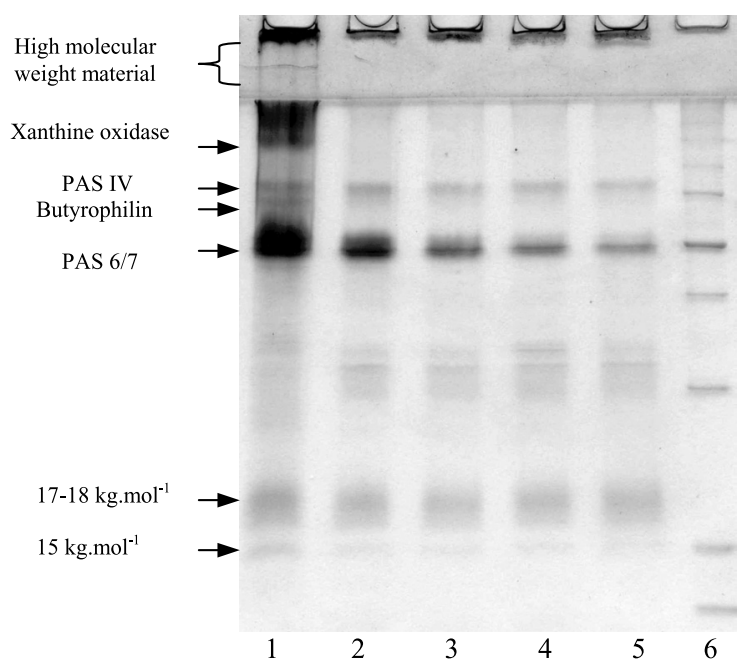

Figure 3. SDS-PAGE patterns (15\% acrylamide gel) of membrane material isolated from heated milk under reducing conditions (A) and non-reducing conditions (B). Cream obtained from the heated milks was washed in SMUF containing urea and EDTA. Lane 1: membrane material from unheated milk (control). Lanes 2-5: membrane material from milk heated at $65^{\circ} \mathrm{C}$; for (2) $10 \mathrm{~min}$, (3) $20 \mathrm{~min}$, (4) $30 \mathrm{~min}$ and (5) $40 \mathrm{~min}$. Membrane polypeptides are named according to Mather [18]. 
Table I. Amounts of $\beta-\mathrm{Lg}$ and $\alpha-\mathrm{La}\left(\mathrm{mg} \cdot \mathrm{g}^{-1} \mathrm{fat}\right)$ in the fat globule membrane material isolated from early-, mid- and late-season whole milks* that were heated at different temperatures for $10 \mathrm{~min}$.

\begin{tabular}{lcccccc}
\hline \multirow{2}{*}{$\begin{array}{l}\text { Temperature } \\
\left({ }^{\circ} \mathrm{C}\right)\end{array}$} & \multicolumn{2}{c}{ Early-season milk $(\mathrm{n}=2)$} & \multicolumn{2}{c}{ Mid-season milk $(\mathrm{n}=3)$} & \multicolumn{2}{c}{ Late-season milk $(\mathrm{n}=2)$} \\
\cline { 2 - 7 } & \multicolumn{1}{c}{$\beta$-Lg } & $\alpha$-La & $\beta$-Lg & $\alpha$-La & $\beta$-Lg & $\alpha$-La \\
\hline 65 & $0.10 \pm 0.06^{\# \mathrm{a} \star}$ & & $0.10 \pm 0.04^{\mathrm{a}}$ & & $0.10 \pm 0.07^{\mathrm{a}}$ & \\
70 & $0.23 \pm 0.05^{\mathrm{b}}$ & & $0.20 \pm 0.05^{\mathrm{b}}$ & & $0.21 \pm 0.04^{\mathrm{b}}$ & \\
75 & $0.60 \pm 0.04^{\mathrm{c}}$ & $0.15 \pm 0.04^{\mathrm{a}}$ & $0.39 \pm 0.05^{\mathrm{f}}$ & $0.08 \pm 0.03^{\mathrm{a}}$ & $0.60 \pm 0.04^{\mathrm{c}}$ & $0.10 \pm 0.06^{\mathrm{a}}$ \\
80 & $0.98 \pm 0.07^{\mathrm{e}}$ & $0.20 \pm 0.05^{\mathrm{c}}$ & $0.75 \pm 0.08^{\mathrm{d}}$ & $0.16 \pm 0.04^{\mathrm{b}}$ & $0.81 \pm 0.08^{\mathrm{d}}$ & $0.16 \pm 0.04^{\mathrm{b}}$ \\
85 & $1.05 \pm 0.10^{\mathrm{e}}$ & $0.22 \pm 0.02^{\mathrm{c}}$ & $0.87 \pm 0.08^{\mathrm{e}}$ & $0.20 \pm 0.04^{\mathrm{c}}$ & $0.88 \pm 0.10^{\mathrm{e}}$ & $0.18 \pm 0.05^{\mathrm{c}}$ \\
90 & $1.12 \pm 0.08^{\mathrm{e}}$ & $0.23 \pm 0.05^{\mathrm{c}}$ & $0.90 \pm 0.05^{\mathrm{e}}$ & $0.21 \pm 0.03^{\mathrm{c}}$ & $1.00 \pm 0.06^{\mathrm{e}}$ & $0.25 \pm 0.04^{\mathrm{c}}$ \\
95 & $1.10 \pm 0.10^{\mathrm{e}}$ & $0.25 \pm 0.04^{\mathrm{c}}$ & $0.90 \pm 0.04^{\mathrm{e}}$ & $0.23 \pm 0.02^{\mathrm{c}}$ & $0.98 \pm 0.08^{\mathrm{e}}$ & $0.25 \pm 0.04^{\mathrm{c}}$ \\
\hline
\end{tabular}

* Early-, mid- and late-season milks were collected in August, January to March and May, respectively; \# data are means \pm sample standard deviations; ${ }^{\star}$ different superscripts within a row or a column indicate significant differences $(P<0.05)$.

Table II. Amounts of $\beta-\mathrm{Lg}$ and $\alpha-\mathrm{La}\left(\mathrm{mg} \cdot \mathrm{g}^{-1}\right.$ fat) in the fat globule membrane material isolated from early-, mid- and late-season whole milks* that were heated at $70{ }^{\circ} \mathrm{C}$ for different times.

\begin{tabular}{ccccccc}
\hline \multirow{2}{*}{$\begin{array}{l}\text { Time } \\
(\mathrm{min})\end{array}$} & \multicolumn{2}{c}{ Early-season milk $(\mathrm{n}=2)$} & \multicolumn{2}{c}{ Mid-season milk $(\mathrm{n}=4)$} & \multicolumn{2}{c}{ Late-season milk $(\mathrm{n}=2)$} \\
\cline { 2 - 7 } & \multicolumn{1}{c}{$\beta$-Lg } & $\alpha$-La & $\beta$-Lg & $\alpha$-La & $\beta$-Lg & $\alpha$-La \\
\hline 2.5 & $0.15 \pm 0.02^{\# \mathrm{a} \star}$ & & $0.13 \pm 0.04^{\mathrm{a}}$ & & $0.16 \pm 0.04^{\mathrm{a}}$ & \\
5 & $0.18 \pm 0.05^{\mathrm{b}}$ & & $0.15 \pm 0.02^{\mathrm{b}}$ & & $0.18 \pm 0.03^{\mathrm{b}}$ & \\
10 & $0.23 \pm 0.04^{\mathrm{c}}$ & & $0.20 \pm 0.03^{\mathrm{c}}$ & & $0.21 \pm 0.05^{\mathrm{c}}$ & \\
15 & $0.37 \pm 0.04^{\mathrm{d}}$ & $0.06 \pm 0.02^{\mathrm{a}}$ & $0.26 \pm 0.06^{\mathrm{d}}$ & $0.06 \pm 0.01^{\mathrm{a}}$ & $0.29 \pm 0.06^{\mathrm{d}}$ & $0.03 \pm 0.06^{\mathrm{a}}$ \\
20 & $0.43 \pm 0.05^{\mathrm{f}}$ & $0.10 \pm 0.02^{\mathrm{b}}$ & $0.32 \pm 0.05^{\mathrm{e}}$ & $0.07 \pm 0.01^{\mathrm{b}}$ & $0.35 \pm 0.08^{\mathrm{e}}$ & $0.06 \pm 0.05^{\mathrm{b}}$ \\
30 & $0.52 \pm 0.06^{\mathrm{e}}$ & $0.12 \pm 0.01^{\mathrm{b}}$ & $0.41 \pm 0.06^{\mathrm{f}}$ & $0.07 \pm 0.02^{\mathrm{b}}$ & $0.40 \pm 0.08^{\mathrm{f}}$ & $0.09 \pm 0.05^{\mathrm{b}}$ \\
40 & $0.67 \pm 0.06^{\mathrm{h}}$ & $0.14 \pm 0.03^{\mathrm{b}}$ & $0.56 \pm 0.08^{\mathrm{g}}$ & $0.10 \pm 0.01^{\mathrm{b}}$ & $0.58 \pm 0.07^{\mathrm{g}}$ & $0.10 \pm 0.04^{\mathrm{b}}$ \\
\hline
\end{tabular}

* Early-, mid- and late-season milks were collected in August, January to March and May, respectively; \# data are means \pm sample standard deviations; ${ }^{\star}$ different superscripts within a row or a column indicate significant differences $(P<0.05)$.

of $\beta$ - $\operatorname{Lg}$ and $\alpha$-La associated with the MFGM in heated mid-season milk were $\sim 0.9 \mathrm{mg} \cdot \mathrm{g}^{-1}$ fat and $\sim 0.23 \mathrm{mg} \cdot \mathrm{g}^{-1}$ fat, respectively. These saturating $\beta-\mathrm{Lg}$ and $\alpha-$ La values were $\sim 15 \%$ and $\sim 3 \%$ of the total MFGM proteins. However, this represents only $\sim 1 \%$ and $\sim 0.8 \%$ of the total $\beta$-Lg and $\alpha$-La in milk (calculated from $0.4 \% \beta$-Lg and $0.16 \% \alpha$-La in $4.5 \%$ fat whole milk). The associations of $\beta$ - $\mathrm{Lg}$ and $\alpha-\mathrm{La}$ with the
MFGM in early-season heated milk $\left(\sim 1.1 \mathrm{mg} \cdot \mathrm{g}^{-1}\right.$ fat and $\sim 0.25 \mathrm{mg} \cdot \mathrm{g}^{-1}$ fat $)$ were slightly higher than those in mid-season milk, whereas the amounts of $\beta-\mathrm{Lg}$ and $\alpha$-La associated with the MFGM in lateseason heated milk were intermediate between those in early- and mid-season milks (Tab. I). For milks heated at $70{ }^{\circ} \mathrm{C}$ for various times (Tab. II), the amounts of $\beta-\mathrm{Lg}$ and $\alpha-\mathrm{La}$ associated with the MFGM 
increased with an increase in heating time; larger amounts of $\beta$-Lg and $\alpha$-La were associated with the MFGM in the early-season milk compared with the mid- and lateseason milks.

A number of authors [7, 11, 17] have reported the presence of $\beta-\mathrm{Lg}$ in the MFGM of heated milk. In studies where quantitative data were obtained [5, 22], the maximum amounts of $\beta-\mathrm{Lg}$ associated with the MFGM of heated milk were $\sim 0.7 \mathrm{mg} \cdot \mathrm{g}^{-1}$ fat. This value is similar to the results obtained in the present study.

In the case of $\alpha-\mathrm{La}$, the findings of previous studies are contradictory. On the one hand, Corredig and Dalgleish [5] found a maximum amount for $\alpha$-La in the MFGM of heated milk of $0.22 \mathrm{mg} \cdot \mathrm{g}^{-1}$ fat. On the other hand, Dalgleish and Banks [7] did not detect $\alpha$-La in fat globule membrane preparations from milks that had been heated at $80^{\circ} \mathrm{C}$ and, although Houlihan et al. [11] reported a low level of $\alpha$-La in all heated samples, they considered that it was an artifact.

Although the amount of $\kappa$-casein associated with the MFGM is very small, its occurrence raises the question of whether the casein micelle is present in the MFGM after heating, as $\mathrm{K}$-casein is one component of the casein micelle. Figure 4 shows the SDSPAGE protein patterns, under reducing and non-reducing conditions, of MFGM material isolated from milk heated in the range $65-95^{\circ} \mathrm{C}$ for $10 \mathrm{~min}$, in which the cream, obtained from the heated milk, was washed using SMUF in the absence of the dissociating agent (urea and EDTA). Under reducing conditions, in addition to the $\kappa$-casein band, $\alpha_{\mathrm{s} 1^{-}}, \alpha_{\mathrm{s} 2^{-}}$and $\beta$-casein bands were also observed in milk samples heated at temperatures $>80^{\circ} \mathrm{C}$. Bands of $\alpha_{s^{-}}$and $\beta$ casein were also observed in SDS-PAGE under non-reducing conditions, but the $\kappa$ casein, $\beta$-Lg and $\alpha$-La bands disappeared (Fig. 4B). These results suggest that the casein micelles may be directly associated with the MFGM proteins through $\kappa$-casein. Alternatively, $\beta-\mathrm{Lg}$ could associate with the MFGM via sulfydryl-disulfide interchange with the MFGM proteins, and subsequently interact with the casein micelles through $\kappa$-casein.

The intensities of xanthine oxidase, butyrophilin, GPT-binding proteins and $15 \mathrm{~kg} \cdot \mathrm{mol}^{-1}$ polypeptide bands were not affected by heat treatment (Fig. 1A and 2A). However, the intensity of PAS 7 (Band 16) band markedly decreased with increases in temperature and heating time, and this band almost disappeared from the PAGE gels after heating at $>75^{\circ} \mathrm{C}$ for $10 \mathrm{~min}$ (Fig. 1A) or $70^{\circ} \mathrm{C}$ for $>20 \mathrm{~min}$ (Fig. 2A). In addition, there was a slight decrease in the intensity of PAS 6 (band 15) with increases in temperature and heating time (Fig. 1A). Figure 5 shows the change in the amounts of individual MFGM proteins in different season milks during heat treatments at $60-95{ }^{\circ} \mathrm{C}$ for $10 \mathrm{~min}$. These data show the same trends for xanthine oxidase, butyrophilin, PAS 6 and PAS 7 as described above. It must be pointed out that the values reported in Figure 5 are based on staining intensity, which may vary between protein species. Hence, they may not represent actual protein content, but will highlight differences between samples of the same protein and changes during processing. Houlihan et al. [10] also found that PAS 6 and PAS 7 were lost from the MFGM of milk heated at $80{ }^{\circ} \mathrm{C}$ for $20 \mathrm{~min}$; however, they observed a marked reduction in xanthine oxidase, which is in contrast to the findings of this study.

In SDS-PAGE under non-reducing conditions, no bands were observed for $\beta-\mathrm{Lg}$, $\alpha$-La and $\kappa$-casein for both the heated milk samples and the unheated control sample (Figs. 1B, 2B and 3B). All the major proteins of the original MFGM decreased in intensity with an increase in temperature or heating time with a corresponding increase in the amounts of high molecular weight material, which remained on the top of the stacking gel. Comparison of the PAGE protein patterns under reducing (Figs. 1A and $2 \mathrm{~A}$ ) and non-reducing (Figs. $1 \mathrm{~B}$ and 


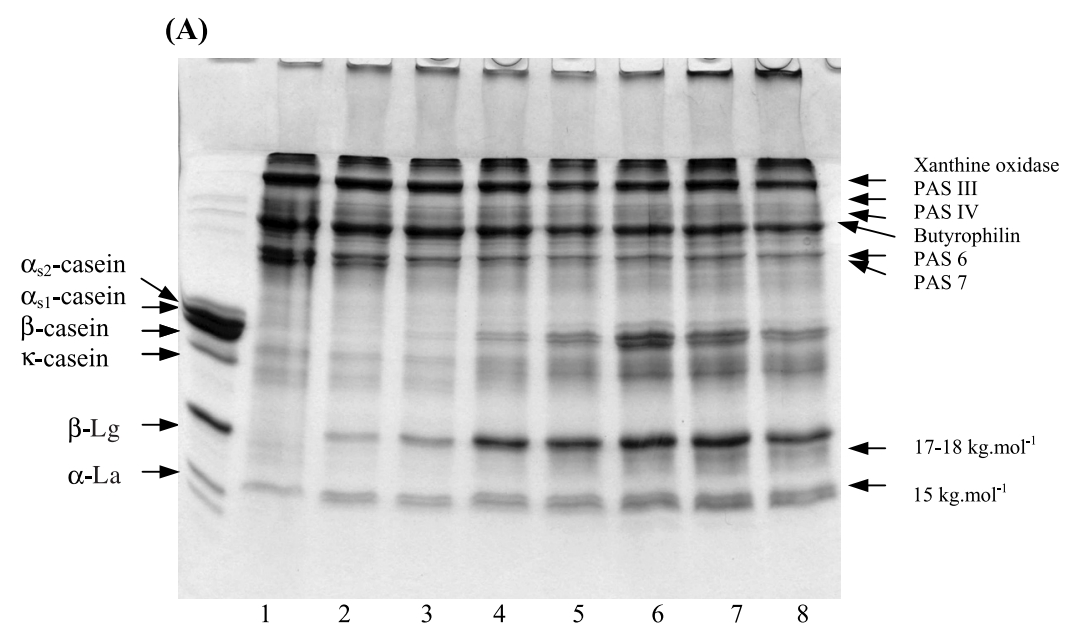

(B)

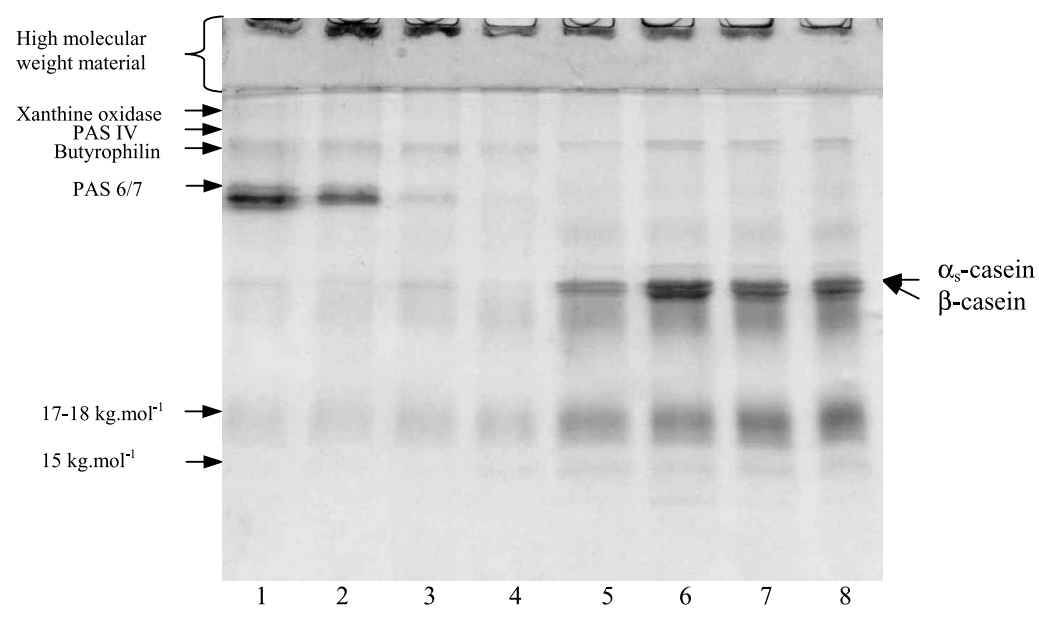

Figure 4. SDS-PAGE patterns (15\% acrylamide gel) of membrane material isolated from heated milk under reducing conditions (A) and non-reducing conditions (B). Cream obtained from the heated milks was washed in SMUF only. Lane 1: membrane material from unheated milk (control). Lanes 2-8: membrane material from milk heated at $65-95^{\circ} \mathrm{C}$, for $10 \mathrm{~min}$; (2) $65^{\circ} \mathrm{C}$, (3) $70{ }^{\circ} \mathrm{C}$, (4) $75^{\circ} \mathrm{C}$, (5) $80^{\circ} \mathrm{C}$, (6) $85^{\circ} \mathrm{C}$, (7) $90{ }^{\circ} \mathrm{C}$ and (8) $95^{\circ} \mathrm{C}$. Membrane polypeptides are named according to Mather [18].

2B) conditions showed that the changes in PAS 7 band intensity were similar, in that the band intensity markedly decreased with increasing heating time at $65{ }^{\circ} \mathrm{C}$ and $70{ }^{\circ} \mathrm{C}$, and the band almost disappeared from the PAGE gels at $75{ }^{\circ} \mathrm{C}$ for $10 \mathrm{~min}$ (Fig. 1) or $70{ }^{\circ} \mathrm{C}$ for $20 \mathrm{~min}$ (Fig. 2). This indicates that PAS 7 is removed from the
MFGM before it interacts with other membrane proteins via sulfydryl-exchange reactions.

The protein complexes observed in the SDS-PAGE gels under non-reducing conditions were further characterized using twodimensional SDS-PAGE (non-reducing, then reducing). The resultant protein patterns 

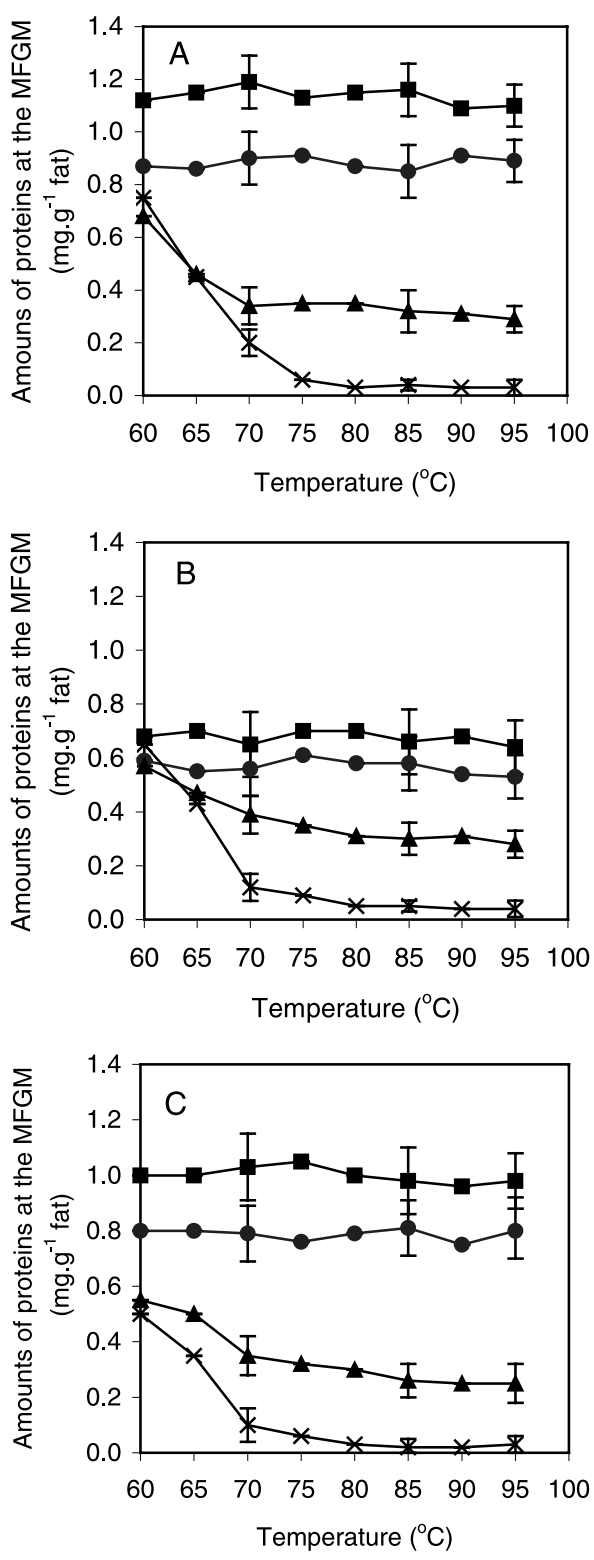

Figure 5. Amounts of xanthine oxidase $(\bullet)$, butyrophilin $(\boldsymbol{\nabla}), \operatorname{PAS} 6(\boldsymbol{\Delta})$ and PAS $7(\boldsymbol{X})$ in the fat globule membrane material isolated from early- (A), mid- (B) and late- (C) season milks heated at $60-95^{\circ} \mathrm{C}$ for $10 \mathrm{~min}$. for MFGM material from milk heated at $65{ }^{\circ} \mathrm{C}$ for $30 \mathrm{~min}$ and at $80{ }^{\circ} \mathrm{C}$ for $10 \mathrm{~min}$ are shown in Figure 6; a control sample was run on the left of the second dimension gel to assist identification of the proteins. In the milk sample heated at $65^{\circ} \mathrm{C}$ for 30 min, almost all the original MFGM polypeptides (including xanthine oxidase, butyrophilin, PAS 6, PAS 7 and GPT-binding proteins) and $\beta$ - $\mathrm{Lg}$ were found in the lane resolved from the high molecular weight protein material present at the top of the stacking gel of the first dimension (Fig. 6A). Some of the PAS 6/7 proteins, which migrated into the resolving gel in the first dimension, were observed as an intense spot in the second dimension. Although some of the $17-18 \mathrm{~kg} \cdot \mathrm{mol}^{-1}$ and $15 \mathrm{~kg} \cdot \mathrm{mol}^{-1}$ polypeptides were resolved from the high molecular weight material at the top of stacking gel of the first dimension, more intense spots were observed from the bands that migrated into the resolving gel of the first dimension. In the milk sample heated at $80^{\circ} \mathrm{C}$ for $10 \mathrm{~min}$, the results were similar to those for the sample heated at the lower temperature $\left(65^{\circ} \mathrm{C}\right.$ for $30 \mathrm{~min}$ ), with the exceptions of PAS 7 which was absent from the gel and $\beta-\mathrm{Lg}$ which gave a more intense spot when resolved from the high molecular weight protein material at the top of the stacking gel of the first dimension (Fig. 6B).

\section{DISCUSSION}

The results clearly show that $\beta$-Lg was present in the MFGM of milk that was heated at relatively low temperatures, namely $60-65{ }^{\circ} \mathrm{C}$ (Figs. $1 \mathrm{~A}$ and $2 \mathrm{~A}$ ). Furthermore, two-dimensional SDS-PAGE clearly indicated that $\beta-\mathrm{Lg}$ was associated with the original MFGM proteins via disulfide bonds in this temperature range (Fig. 6). This temperature range is lower than that required to denature this protein; the denaturation temperature of $\beta-\mathrm{Lg}$ has been reported to be $78^{\circ} \mathrm{C}$, using differential scanning calorimetry $[8,18]$. However, it has been found that some MFGM proteins 

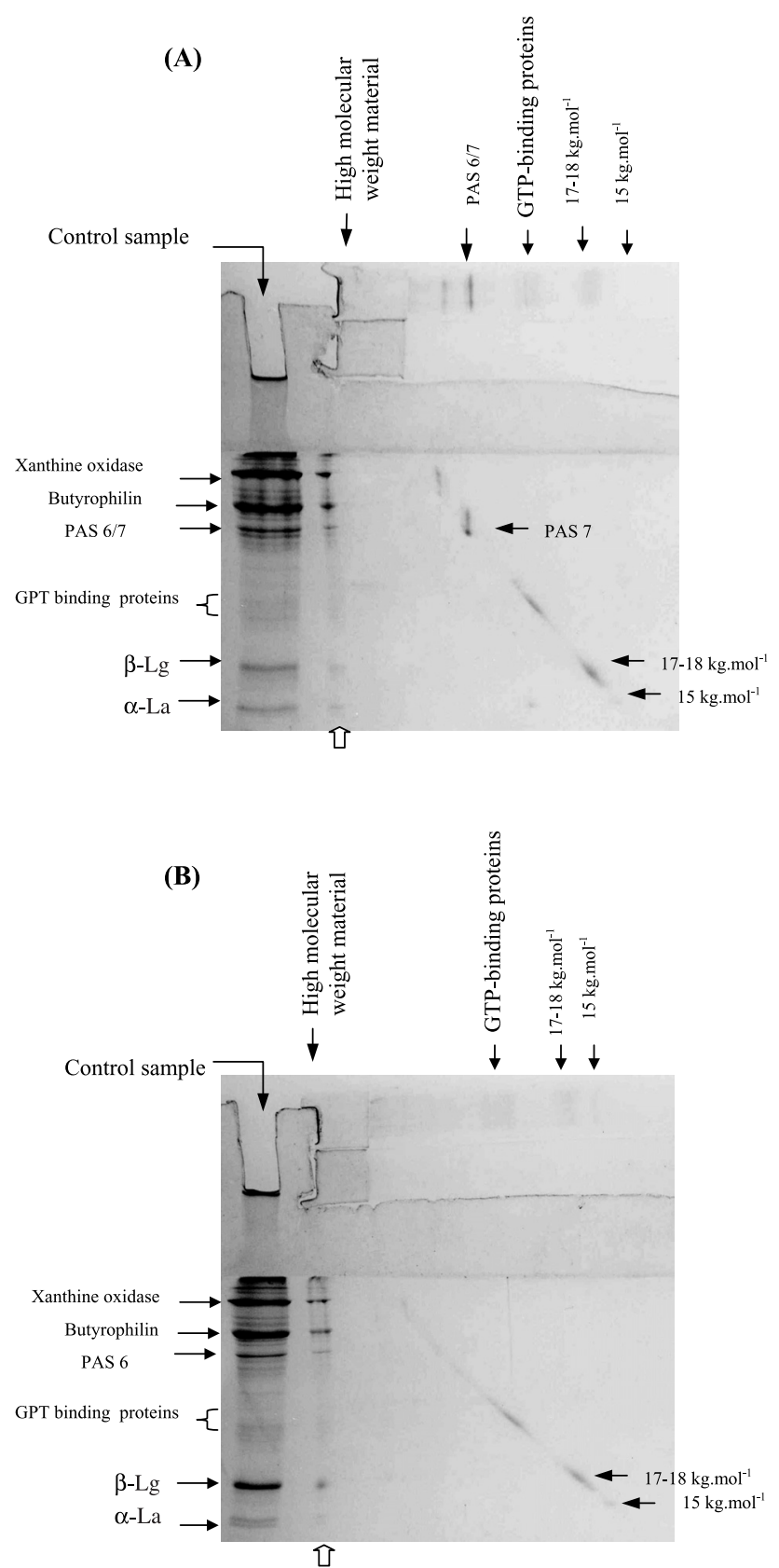

Figure 6. Two-dimensional SDS-PAGE patterns (15\% acrylamide gel) of membrane material isolated from milks heated at $65^{\circ} \mathrm{C}$ for $30 \mathrm{~min}$ (A) and $80^{\circ} \mathrm{C}$ for $10 \mathrm{~min}$ (B). Cream obtained from the heated milks was washed in SMUF containing urea and EDTA. First (horizontal) dimension: SDS-PAGE under non-reducing conditions; second (vertical) dimension: SDS-PAGE under reducing conditions. Membrane polypeptides are named according to Mather [18]. 
denature at low temperatures, about $60{ }^{\circ} \mathrm{C}$ $[2,23]$. Corredig and Dalgleish [6] found that iron released from the xanthine oxidase when cream was heated at $\geq 62{ }^{\circ} \mathrm{C}$. They suggest that the release of iron would render the cysteines of the membrane protein available for disulfide exchange with other cysteine-containing proteins present in the cream. MFGM proteins contain a large amount of disulfide and sulfydryl groups [4]. For example, xanthine oxidase, one of the major MFGM proteins, contains 22 disulfide and 38 sulfydryl groups, four of which are detectable in the undenatured protein complex. This may imply that the free thiol groups could be provided by the MFGM proteins, for initiating thioldisulfide interchange between MFGM proteins and $\beta$-Lg.

The above discussion suggests that the association of $\beta-\mathrm{Lg}$ with the MFGM probably occurs after the native $\beta$ - $\mathrm{Lg}$ dimer has dissociated to monomers, but before the free thiol grouping of $\beta-\mathrm{Lg}$ has been exposed. Dalgleish and Banks [7] and Corredig and Dalgleish [5] also found that the interaction of $\beta-\mathrm{Lg}$ with the fat globules occurred at relatively low temperatures $\left(65-70{ }^{\circ} \mathrm{C}\right)$ and was completed before all of the serum proteins had been denatured. However, they could not distinguish between the mechanism involving the disulfide bonding and the physical adsorption of $\beta$ - $\mathrm{Lg}$ directly at the fat-water interface. In contrast, the findings of Houlihan et al. [11] indicate that, when whole milk was heated to $80^{\circ} \mathrm{C}$, the serum proteins were denatured exposing the thiol groups, prior to their incorporation into membrane proteins.

The association of $\alpha$-La with the MFGM proteins occurs as a result of sulfydryl exchange in a similar manner to that exhibited by $\beta$-Lg. In both cases, this mechanism operates at $\geq 65^{\circ} \mathrm{C}$ although much lower quantities of $\alpha$-La are incorporated into the membrane compared with $\beta-\mathrm{Lg}$.

Furthermore, small amounts of $\kappa$ casein also associate with the MFGM via disulfide bonds as indicated by comparison of SDS-PAGE under reducing and nonreducing conditions. Similar results were reported by Houlihan et al. [11], who showed that the incorporation of $\kappa$-casein into the MFGM increased as heating time at $80{ }^{\circ} \mathrm{C}$ increased. However, Dalgleish and Banks [7] considered that the presence of casein on the surfaces of the fat globules may have been a result of inadvertent partial homogenization during the handling of the milk and they did not support the suggestion that the $\kappa$-casein either associated with the MFGM proteins or formed $\kappa$ casein/ $\beta$-Lg complexes on the fat globule surface. These authors observed little or no increase in $\mathrm{K}$-casein in heated milk samples even when substantial increases in $\beta-\mathrm{Lg}$ occurred.

In our study, only $\kappa$-casein is observed on the SDS-PAGE of the heated MFGM material that had been washed using the micelle dissociating buffer. However, when the MFGM material is washed using the SMUF solution (i.e. no micelle dissociation), other caseins including $\kappa$-casein are observed on the SDS-PAGE. Therefore, these observations strongly suggest that the casein micelles associate with the MFGM via the disulfide bonding between $\kappa$-casein and MFGM components. In all previous work, only one kind of buffer was used in the washing procedure, which makes it impossible to conclude whether casein micelle or individual casein molecules associate with the MFGM during the heating of whole milk.

The non-reducing SDS-PAGE (Figs. 1B and 2B) and two-dimensional PAGE (Fig. 6) results showed that most of the original MFGM proteins except PAS $7\left(49 \mathrm{~kg} \cdot \mathrm{mol}^{-1}\right)$ were involved in interactions with either serum proteins or other MFGM proteins during heating. As for other MFGM proteins, the intensity of the PAS 7 band decreased during heating from SDS-PAGE under non-reducing conditions. However, unlike the others, it also decreased and finally disappeared from SDS-PAGE under reducing conditions, indicating that 
this protein migrated into the serum phase during heating. In the absence of serum proteins, PAS 7 does not associate with other MFGM proteins via disulfide bonds upon heating, but, interestingly, is more heat stable than the other MFGM proteins [23]. A possible explanation for this difference in behavior is that the presence of serum proteins, particularly $\beta$ - $\mathrm{Lg}$, results in the formation of $\beta-\mathrm{Lg} / \mathrm{MFGM}$ complexes, which may alter the membrane structure and environment, resulting in the removal of PAS 7. An alternative suggestion is that PAS 7 could interact directly with $\beta$-Lg to form $\beta$-Lg/PAS 7 complexes, which then move from the MFGM to the serum phase. Houlihan et al. [11] also observed that the loss of components 15 and 16 (PAS 6/7) from membrane material in heated milk was related to the presence of skim milk components during heating. Kim and Jimenez-Flores [17] also found that this band (PAS 7) decreased in intensity during the heating of milk. However, these authors interpreted this decrease as a breakdown in the structure of this protein with the protein remaining within the MFGM.

The slightly higher amounts of $\beta-\mathrm{Lg}$ associated with the MFGM in heated earlyseason milk (Tab. I) can probably be attributed to the higher concentrations of total MFGM proteins in early-season milk, as reported by Ye et al. [23], which might provide more reaction sites for association with $\beta$ - Lg. An alternative explanation is that the higher concentrations of $\beta-\mathrm{Lg}$ in early-season milk [21] may influence the association of $\beta-\mathrm{Lg}$ with the MFGM. However, the amount of $\beta-\mathrm{Lg}$ associated with the MFGM in heated milk is only $\sim 1 \%$ of the total $\beta-\mathrm{Lg}$ in milk, and hence it is doubtful that small changes in the concentration of $\beta-\mathrm{Lg}$ due to seasonal variation would influence the amount that associates with the MFGM proteins.

The results of this study confirm that heat treatment of whole milk causes the association of whey proteins $(\beta-\mathrm{Lg}$ and $\alpha$ La) with the MFGM. These associations commence at relatively low temperatures $\left(60-65{ }^{\circ} \mathrm{C}\right)$, and increase with increasing temperature and heating time. The maximum amounts of whey proteins associating with the MFGM are small, only $1 \%$ and $0.8 \%$ of the total $\beta-\mathrm{Lg}$ and $\alpha-\mathrm{La}$ in the serum, respectively. Most of the original MFGM proteins (e.g. xanthine oxidase and butyrophilin) are not lost from the membrane during heat treatment. However, PAS 7 is heat labile and PAS 6 also declines during heating. Our study identifies the heating temperature and time that initially causes the removal of PAS 6/7 from the MFGM. This temperature is probably a significant index of knowing the intensity of the heat treatment of the whole milk.

The changes in the composition of MFGM are likely to play an important role in determining the functional properties of many dairy products, especially those properties associated with protein stability during renneting, acidification, heat treatments and storage. Interactions between fat globules containing associated whey proteins on their surface could lead to formation of aggregated material during further processing. For example, this could lead to changes in the functionality of milk powders.

Acknowledgements: We gratefully acknowledge financial support from the Fonterra Co-operative Group.

\section{REFERENCES}

[1] AOAC, Official methods of analysis of the association of official analytical chemists (12 Edition), Washington DC, USA, 1974.

[2] Appell K.C., Keenan T.W., Low P.S., Differential scanning calorimetry of milk fat globule membranes, Biochim. Biophys. Acta 69 (1982) 243-250.

[3] Buchheim W., Membranes of milk fat globules - ultrastructural, biochemical and technological aspects, Milchwirtsch. Forschungsber. 38 (1986) 227-246.

[4] Cheng S.G., Koch U., Brunner J.R., Characteristics of purified cows' milk xanthine oxidase and its submolecular characteristics, J. 
Dairy Sci. 71 (1988) 901-916.

[5] Corredig M., Dalgleish D.G., Effect of different heat treatments on the strong binding interactions between whey proteins and milk fat globules in whole milk, J. Dairy Res. 63 (1996) 441-449.

[6] Corredig M., Dalgleish D.G., Buttermilk properties in emulsions with soybean oil as affected by fat globule, J. Food Sci. 63 (1998) 476-480.

[7] Dalgleish D.G., Banks J.M., The formation of complexes between serum proteins and fat globules during heating of whole milk, Milchwissenschaft 46 (1991) 75-78.

[8] de Wit J.N., Klarenbeek G., Effects of various heat treatments on structure and solubility of whey proteins, J. Dairy Sci. 67 (1984) 2701-2710.

[9] Fink A., Kessler H.G., Changes in the fat globule membrane produced by heating, Milchwissenschaft 40 (1985) 261-264.

[10] Havea P., Singh H., Creamer L.K., Campanella O.H., Electrophoretic characterization of the protein products formed during heat treatment of whey protein concentrate solutions, J. Dairy Res. 65 (1998) 79-91.

[11] Houlihan A.V., Goddard P.A., Nottingham S.M., Kitchen B.J., Masters C.J., Interactions between the bovine milk fat globule membrane and skim milk components on heating whole milk, J. Dairy Res. 59 (1992) 187-195.

[12] IDF, Milk-Determination of fat content (Rose Gottlieb) Standard 1 D. Int. Dairy Fed. Brussels, Belgium, 1987.

[13] IDF, Cream-Determination of fat content (Rose Gottlieb) Standard 16 C. Int. Dairy Fed. Brussels, Belgium, 1987.

[14] Jenness R., Koops J., Preparation and properties of salt solution which simulates milk ultrafiltrate, Neth. Milk Dairy J. 16 (1962) 153-167.

[15] Keenan T.W., Dylewski D.P., Intracellular origin of milk lipid globules and the nature and structure of the milk lipid globule membrane, in: Fox P.F. (Ed.), Advanced dairy chemistry. Volume 2: Lipids, Chapman \& Hall, London, UK, 1995, pp. 89-130.

[16] Keenan T.W., Moon T.W., Dylewski D.P., Lipid globules retain globule membrane material after homogenization, J. Dairy Sci. 66 (1983) 196-203.

[17] Kim H.H.Y., Jimenez-Flores R., Heat-induced interactions between the proteins of milk fat globule membrane and skim milk, J. Dairy Sci. 78 (1995) 24-35.

[18] Kinsella J.E., Whitehead D.M., Proteins in whey: chemical, physical and functional properties, Adv. Food Nutr. Res. 33 (1989) 343-438.

[19] Mather I.H., A review and proposed nomenclature for major proteins of the milk-fat globule membrane, J. Dairy Sci. 83 (2000) 203-247.

[20] Patton S., Huston G.E., A method for isolation of milk fat globules, Lipids 21 (1986) 170-174.

[21] Sanderson W.B., Seasonal variations of some milk protein components. XVIII Int. Dairy Congr. 12-16 October, Sydney, Australia, Vol. 1, 1970, p. 30.

[22] Sharma S.K., Dalgleish D.G., Effect of heat treatments on the incorporation of milk serum proteins into the fat globule membrane of homogenized milk, J. Dairy Res. 61 (1993) 375-384.

[23] Ye A., Singh H., Taylor M.W., Anema S., Characterization of protein components of natural and heat-treated milk fat globule membranes, Int. Dairy J. 12 (2002) 393-402. 